\title{
APLASIA MEDULA COMO SUSPEITAR NA PEDIATRIA: UM RELATO DE CASO Pôster
}

Autores deste trabalho:

Lineke Gonçalves Dias: Hospital Infantil Cândido Fontoura

Mariana Aparecida Brunossi Moura Proença : Hospital Infantil Cândido Fontoura

Pedro Teles de Mendonça Neto: Hospital Infantil Cândido Fontoura

Maryana Beltrão de Carvalho: Hospital Infantil Cândido Fontoura

Rafaela Oliveira Tavares: Hospital Infantil Cândido Fontoura

Ingrid Lacerda Pessoa: Hospital Infantil Cândido Fontoura

João Pedro de Figueiredo Jordão Furtado de Mendonça: Hospital Infantil Cândido Fontoura

Bruna dos Santos Ibiapina Neres: Hospital Infantil Cândido Fontoura

Área do Trabalho: Pediatria

Data da submissão: $10 / 08 / 2018$ às $15: 12$

\section{Justificativa}

A aplasia medular ou anemia aplástica (AA) é uma doença rara com incidência cerca de 1-3:1.000.000, definida pela disfunção da medula óssea, acarretando assim na diminuição da série branca e vermelha. Pode ser desencadeada por diversas causas, adquiridas ou congênitas.

Objetivo(s) Não se aplica Método(s) Não se aplica

\section{Resultado(s)}

A.L.N.F, 1 ano e 7 meses, feminino, previamente hígida, natural e procedente de São Paulo, com história clinica de febre há 22 dias, procurou previamente atendimento na emergência onde foi liberada com antibioticoterapia em 2 ocasiões, devido otite e pneumonia. Na admissão apresentava-se com palidez cutâneo-mucosa, astenia, febril ao tato e hepatoesplenomegalia discreta. Os exames laboratoriais evidenciavam pancitopenia com neutropenia grave (leuco 2800 com 2\% de neutrófilos), reticulócitos de $2 \%$ e alterações de provas inflamatórias. Demais exames sem alterações. O mielograma demonstrou medula óssea intensamente hipocelular. Devido quadro clínico prolongado e após afastar outros diagnósticos diferenciais, feita hipótese de AA.

\section{Conclusão (ões)}

A AA adquirida apresenta-se em 2 picos, o primeiro deles entre 10 e 25 anos e o segundo após os 60 anos, e a congênita entre 2 e 5 anos. Dentre as adquiridas temos por exposição a inseticidas, anti-convulsivantes, cloranfenicol entre outros, após infecção viral, secundário a neoplasia ou outras doenças como tuberculose, hemoglobinúria paroxística noturna etc. O diagnóstico pelo Ministério da Saúde é realizado pela associação de pancitopenia, baixa contagem de reticulócitos e medula óssea hipocelular com diminuição de todos os elementos hematopoiéticos e seus 
precursores, na ausência de células estranhas à medula óssea, fibrose ou hematofagocitose. O tratamento de AA varia de acordo com a gravidade da doença. Dentre eles encontra-se transfusões de hemoconcentrados e antibioticoterapia conforme necessidade. Nos casos graves indica- se o transplante de células-tronco hematopoiéticas (TCTH) alogênico ou terapia imunossupressora combinada. 